Up-regulation of CX3CR1 on tonsillar $\mathrm{CD} 8^{+} \mathrm{T}$ cells in patients with

\title{
IgA nephropathy
}

（邦題: IgA腎症扁桃CD8陽性T細胞上のCX3CR1は高発現してい る)

\section{大高 隆輝}

（高原 幹、上田 征吾、長門 利純、岸辺 幹、片田 彰博、 林 達哉、原㴊 保明） 
研 究目的

IgA 腎症はIgAが腎糸球体に沈着することが特徵とされる、最も一般的な糸球体腎炎である 。当初予後良好と考えられていたが、その後、発症 20-30年後には患者の 30-40\%が末期腎 不全に陥る予後不良であることが明らかにされている。本疾患は上気道炎、特に扁桃炎に 伴い悪化し、以前から耳鼻咽喉科領域では代表的な扁桃病巣疾患として知られてきた。最 近では扁桃摘出術+ステロイドパルス療法がその長期予後に有効であることが示され、腎臟 内科の分野でも標準的治療としてガイドラインに示されている。我々はこのように臨床的 に実証されている口蓋扁桃とIgA 腎症の関係性について基礎的なエビデンスを追求してき た。その結果、IgA 腎症患者の口蓋扁桃からのIgA過剩産生にBAFF(B cell activating factor of the TNF family) が関与していることを明らかにした（ 1 )。しかし、まだその全貌が 理解されているとは言えない。

$\operatorname{IgA}$ 免疫複合体の腎糸球体への沈着以外に、それに続発する T 細胞の浸潤も IgA 腎症進展 に重要な役割を果たしていることが報告されている。腎組織に浸潤している T 細胞上に発 現しているケモカインレセプターの中で、CX3CR1 はその血尿の程度と末梢血 CD8 陽性 T 細 胞やNK 細胞上の CX3CR1 発現に相関があり、CX3CR1 のリガンドであるフラクタルカインが 腎糸球体に発現していることが近年報告された $(2)$ 。以前我々は IgA 腎症扁桃、末梢血で の $\mathrm{T}$ 細胞レパトア解析を行い、扁桃 $\mathrm{T}$ 細胞が I gA 腎症の腎組織に浸潤する可能性を示した ( 3 )。したがって、扁桃 CX3CR1 陽性 T 細胞がその浸潤を担っている可能性がある。しか し、IgA 腎症扁桃におけるCX3CR1を検討した報告はない。

今回我々は、(1) IgA腎症患者扁桃組織や単核球での CX3CR1 の発現、invitroにおける 微生物 DNA $(\mathrm{CpG}-0 \mathrm{DN})$ 等の刺激による CX3CR1 の発現変化、フラクタルカインへの遊走能 (2) IgA 腎症患者末梢血単核球での CX3CR 1 の発現と、口蓋扁桃摘出による発現変化について検 討し、扁桃 CX3CR1 陽性細胞のIgA腎症の病態における関わりについて考察した。

対象・方 法

1. 患者検体

2012 年から 2014 年までに旭川医科大学耳鼻咽喉科・頭頸部外科で口蓋扁桃摘出術を施行 した IgA 腎症患者 20 名、非 IgA 腎症患者 25 名の患者検体（扁桃、腎生検組織、未梢血） を使用した。全検体はインフォームドコンセントを得た上で研究に使用された。

2. 免疫組織染色

口蓋扁桃、腎生検のホルマリン固定パラフィン包埋切片を作成し、抗 CX3CR1、抗フラク 
タルカイン抗体を用いて免疫染色を行った。扁桃において顕微鏡下にCX3CR1 陽性細胞数を カウントし、 $1 \mathrm{~mm} 2$ の陽性細胞数を計測した。

\section{3. 細胞分離}

口蓋扁桃を細断、濾過し比重遠沈法にて扁桃単核球を分離、無菌PBSで 5 回洗浄した。 扁桃摘出前と 1 ケ月後に患者より採血を行い、未梢血より末梢血単核球を同様に分離した

\section{Two-color flow cytometry}

PE 標識抗 CX3CR1 抗体、FITC 標識抗 CD8 抗体を用いて扁桃単核球、未梢血単核球におけ る CD8+CX3CR1+細胞数の割合を測定した。

4. Ce11 culture

RPIM 1640 培地 $3 \mathrm{~m} 1$ に $1 \times 106 / \mathrm{m} 1$ の TMCs を添加し、12 時間培養後、各ウェルに $1 \mu \mathrm{M} \mathrm{CPG-ODN}$ 、1 $1 \mu \mathrm{M}$ non-CPG(Control) ODN、50ng/ml recombinant IFN- $\gamma 、 1 \mu \mathrm{g} / \mathrm{ml}$ LPS を添加した。 24 時間後細胞を回収、two-color flow cytometryを行った。

5. Chemotaxis assay

扁桃単核球のフラクタルカインへの遊走能をmigration plateを用いて Chemotaxis assayを施行した。3 種類の濃度 $(0 \mathrm{ng} / \mathrm{m} 1 、 50 \mathrm{ng} / \mathrm{ml} 、 500 \mathrm{ng} / \mathrm{ml})$ の recombinant フラクタ ルカインにて 12 時間培養の後、遊走した細胞数を測定し、遊走能を検討した。

6. 統計学的解析

2 因子間の検討にはMann-Whitney U 検定とSpearmanの順位相関係数、連続変数の検討には Wilcoxonの順位和検定を用いた。いずれも $\mathrm{p}<0.05$ を有意とした。

\section{結 果}

1. 免疫染色による CX3CR1 陽性、フラクタルカイン陽性細胞の分布 IgA 腎症患者扁桃濾胞間に、非 IgA 腎症患者扁桃に比べ有意に多くの陽性細胞数を認めた 。IgA 腎症患者腎組織でも系球体、間質、尿細管にCX3CR 1 陽性細胞を認めた。また、過去 の報告と同様、系球体、間質、尿細管にフラクタルカインの強い染色を認めた。

2. 扁桃、未梢血単核球での Two-color flow cytometry によるCX3CR1の発現

扁桃単核球において IgA 腎症群での CD8+CX3CR 1+細胞数の割合は非 IgA腎症群と比較し有 意に増加していた。また、未梢血単核球において IgA 腎症群での CD8+CX3CR1+細胞数の割合 は非 IgA 腎症群と比較して有意に増加し、口蓋扁桃摘出後その割合は有意に減少していた 。また、口蓋扁桃摘出後の血尿が消失した患者 $(n=10)$ では末梢血 CD 8+CX3CR 1+細胞数の割 
合は減少した一方、消失しなかった患者（n=3）ではその割合は減少していなかった。

3. $\mathrm{CpG}-0 \mathrm{DN}$ 刺激による IgA 腎症患者扁桃 $\mathrm{CD} 8$ 陽性 $\mathrm{T}$ 細胞の CX3CR 1 の発現変化

各種刺激を施行した結果、 $\mathrm{CpG}-0 \mathrm{DN}$ 刺激にて、IgA 腎症群での扁桃単核球 CD $8+C X 3 C R 1+$ 細胞数の割合は有意に増加していた。しかし、非 IgA 腎症群では増加は認められなかった 。また IFN- $\gamma$ 刺激においてはIgA 腎症群、非 IgA 腎症群の両群ともに陽性細胞数の割合が 有意に増加していた。contro1-0DNとLPSによる刺激では両群において変動は認められなか った。

4. TMCs のフラクタルカインへの走化反応

Chemotaxis assayの結果、フラクタルカイン濃度 $500 \mathrm{ng} / \mathrm{m} 1$ において、IgA 腎症群の扁 桃単核球では非 IgA 腎症群と比較して有意に高い遊走能を認めた。

\section{考案}

本研究の結果から、IgA 腎症扁桃 CD 8 陽性リンパ球は微生物 DNA に高頻度で含まれる $\mathrm{CpG}$ 刺激にて IFN- $\gamma$ を介して CX3CR1を過剩発現し、体循環に放出され、フラクタルカインを発 現する腎糸球体にホーミングし、腎炎を促進させる可能性が示唆された。近年、IgA 腎症は IgA 免疫複合体微小血管炎による糸球体腎炎と考えられている。また、CX3CR1 陽性細胞は 細胞傷害活性のあるCD 8 陽性の T 細胞あるいはNK 細胞に発現し、フラクタルカインとの結 合により血管炎を来すことが報告されている。よって扁桃由来の CD 8 +CX3CR 1+細胞が腎組 織にて血管炎を惹起している可能性がある。我々やCox ら（2）が示した血尿との関連はそ の血管炎により促されているかもしれない。さらに、以前より知られている上気道炎や扁 桃炎にて血尿が悪化するメカニズムに扁桃由来のCD 8 +CX3CR1+陽性細胞が関与している可 能性がある。

微生物 DNA に高頻度で含まれる CpG は TLR9に結合し、免疫反応を引き起こす。以前我々 は、 $\mathrm{CpG}-0 \mathrm{DN}$ 刺激により、IgA 腎症扁桃単核球からの IFN- $\gamma$ とAFFの産生が増加すること を示した（1）。今回の検討においても IgA 腎症扁桃での $\mathrm{CpG}-0 \mathrm{DN}$ にる過剩免疫反応が根 幹となっている可能性が示唆される。マウスモデルでの $\mathrm{CpG}$ 鼻腔噴霧により、血中の $\operatorname{IgA}$ 值が上昇し、腎糸球体に IgA が沈着する報告や、TLR9 遺伝子のpolymorphism が IgA 腎症 の病勢に関与している報告は $\mathrm{CpG}-\mathrm{TLR} 9$ がその病態に深く関与していることを物語る。これ らの結果はTLR9 やその下流にある IFN- $\gamma 、$ CX3CR1 が扁桃との関連性を示すマーカーとし て、あるいは治療の標的因子として将来的に応用できる可能性があると考えられた。 
結＼cjkstart論

1. IgA 腎症群における扁桃 $\mathrm{CD} 8+\mathrm{CX} 3 \mathrm{CR} 1+$ 細胞数の割合は非 $\operatorname{IgA}$ 腎症群と比較して有意に 増加していた。

2. $\mathrm{CpG}-0 \mathrm{DN}$ 刺激において、IgA腎症群での扁桃 $\mathrm{CD} 8+\mathrm{CX} 3 \mathrm{CR} 1+$ 細胞数の割合は有意に増加 していた。

3. I gA 腎症群における末梢血単核球の CD8+CX3CR 1+細胞数の割合は非 IgA 腎症群と比較 して有意に増加しており、扁桃摘出後有意に減少した。

4. I I A 腎症群での扁桃単核球のフラクタルカインへの遊走能は有意に六進していた。 5. これらのことから、扁桃由来の CD8+CX3CR $1+$ 細胞が IgA 腎症の病態に関与している 可能性が示唆された。

引用文献

1. Goto T, Bandoh N, Yoshizaki T, Nozawa H, Takahara M, Ueda S, Hayashi T, Harabuchi Y. Increase in B-cell-activation factor (BAFF) and IFN-gamma productions by tonsillar mononuclear cells stimulated with deoxycytidyl-deoxyguanosine oligodeoxynucleotides (CpG-0DN) in patients with IgA nephropathy. Clin Immunol.126:260-269. (2008)

2. Nozawa H, Takahara M, Yoshizaki T, Goto T, Bandoh N. and Harabuchi Y. Selective expansion of T cell receptor (TCR) V beta 6 in tonsillar and peripheral blood T cells and its induction by in vitro stimulation with Haemophilus parainfluenzae in patients with IgA nephropathy. C1in Exp Immuno1.151:25-33. (2007)

3. Cox SN, Sallustiof, Serino G, Loverre A, PesceF, Gigante M, Zaza G, Stifanelli

PF, Ancona N, Schena FP. Activated innate immunity and the involvement of CX3CR1-fractalkine in promoting hematuria in patients with IgA nephropathy. Kidney Int. $82: 548-560 . \quad(2012)$ 